\title{
DACTYLOGYRUS TRIAPPENDIXIS SP. N. (MONOGENEA) PARASITE OF THE TENCH, TINCA TINCA (L.) DACTYLOGYRUS TRLAPPENDIXIS SP. N. (MONOGENEA) PASOŻYT LINA, TINCA TINCA (L.)
}

\section{Department of Fish Diseases, Agricultural University of Szczecin, Poland}

The present paper provides a detailed description of a new species of Monogenea-Dactylogyrus triappendixis, parasitic on gills of tench, Tinca tinca (L.) from the lakes of north-west Poland. The above-mentioned species differs from its congeners, parasitizing the tench, with details of the male copulatory organ and armament of the vagina. It is a frequent parasite of the tench in the water bodies studied, at the temperature of about $18^{\circ} \mathrm{C}$.

\section{INTRODUCTION}

It can be concluded from the data provided by the "Catalogue of parasite fauna of Poland" (Grabda 1971) that a total of four species representing the Dactylogyrus Diesing, 1850 have been recorded from the tench Tinca tinca (L.) in the area studied, namely: D. amphibothrium Wagener, 1857, D. anchoratus (Dujardin, 1845), D. macracanthus Wegener, 1909, and D. vastator Wegener, 1909. According to the most recent literature (Gusev 1985) this host is parasitized by only two host-species: D. macracanthus and D. tincae Gusev, 1965. The former-D. macracanthus was more frequently listed in published works (Markevič 1951; Ergens and Lom 1970; Grabda 1971; Gusev 1965, 1985). On the other hand D. tincae was recorded in the drainage basin of the Danube and Elbe rivers on the territory of the former Czechoslovakia (Gusev 1965, 1985; Ergens and Lom 1970). In addition to that, this species was recorded by Puciłowska (1973) from Zegrzyński Reservoir (Poland). This author did not provide the name of the fish hosts, stating generally their systematic position on the family level (among others-Cyprinidae). Some time later Baturo (1978) recorded the presence of Dactylogyrus sp. on the tench fry in the ponds of north-eastern Poland. 
Presently found parasites differed morphologically from currently known species of the genus Dactylogyrus. It prompted us to describe the specimens recovered, as a new species which we named Dactylogyrus triappendixis sp. $\mathrm{n}$.

\section{MATERIAL AND METHODS}

The fish originated from lakes: Ińsko, Woświn, and Mielno located in the northwestern part of Poland in the province of Szczecin. The material was collected between 14 May and 26 June 1996. A total of 32 tench, Tinca tinca was studied. Their total length ranged from 15.5 to $38.0 \mathrm{~cm}$ and their weight-from 45 to $790 \mathrm{~g}$. Out of the studied fish, 21 came from Ińsko Lake, 6-from Woświn Lake, and 5-from Mielno Lake.

The fish were transferred in tanks filled with water from the lakes to laboratory, where they were kept in aquaria. The necropsies were performed on fresh fish, killed following their anesthetizing with Propiscin. The matter scrapped off the gill arches was examined under a dissecting microscope. The recovered parasites of the genus Dactylogyrus were studied fresh of fixed and cleared with lactophenol after being flattened on a glass slide. The drawings published in the present paper were prepared using a drawing tube. The measurements were based on 20 specimens.

The type specimens were deposited in the Museum of Natural History, Wrocław University (MNHW), Poland (cat. No MP667).

\section{RESULTS}

Dactylogyrus triappendixis sp. $\mathrm{n}$.

Parasitizing gills of tench, Tinca tinca (L.). Relatively big; body length reaching $2.5 \mathrm{~mm}$ and body width $-0.4 \mathrm{~mm}$. Anterior end of body equipped with 4 pigmented-lined eye-spots. First pair smaller, measuring 4-9 $\mu \mathrm{m}$. Second pair bigger-9-14 $\mu \mathrm{m}$. Below eye-spots-muscular pharynx, measuring 68-122 × 108-130 $\mu \mathrm{m}$. Posterior end of body with opisthohaptor armed with two hamuli, 14 marginal hooks, and two connecting bars (Fig. 1).

Central hamuli of opisthohaptor broad, with particularly widened bases of roots. Roots thick and not very long. Inner root distinctly longer than outer (Fig. 1). Total length of hamulus $-50-59 \mu \mathrm{m}$, basal part-38-46 $\mu \mathrm{m}$, inner root $-17-28 \mu \mathrm{m}$, outer root6-17 $\mu \mathrm{m}$, blade- $18-26 \mu \mathrm{m}$.

Marginal hooks having relatively long and wide handles (Fig. 1). Total length of hooks-33-39 $\mu \mathrm{m}$.

Connecting bar (dorsal) slightly narrower in central part. Lateral ends wider and rounded (Fig. 1). Length of bar-10-17 $\mu \mathrm{m}$, width $-45-56 \mu \mathrm{m}$. 


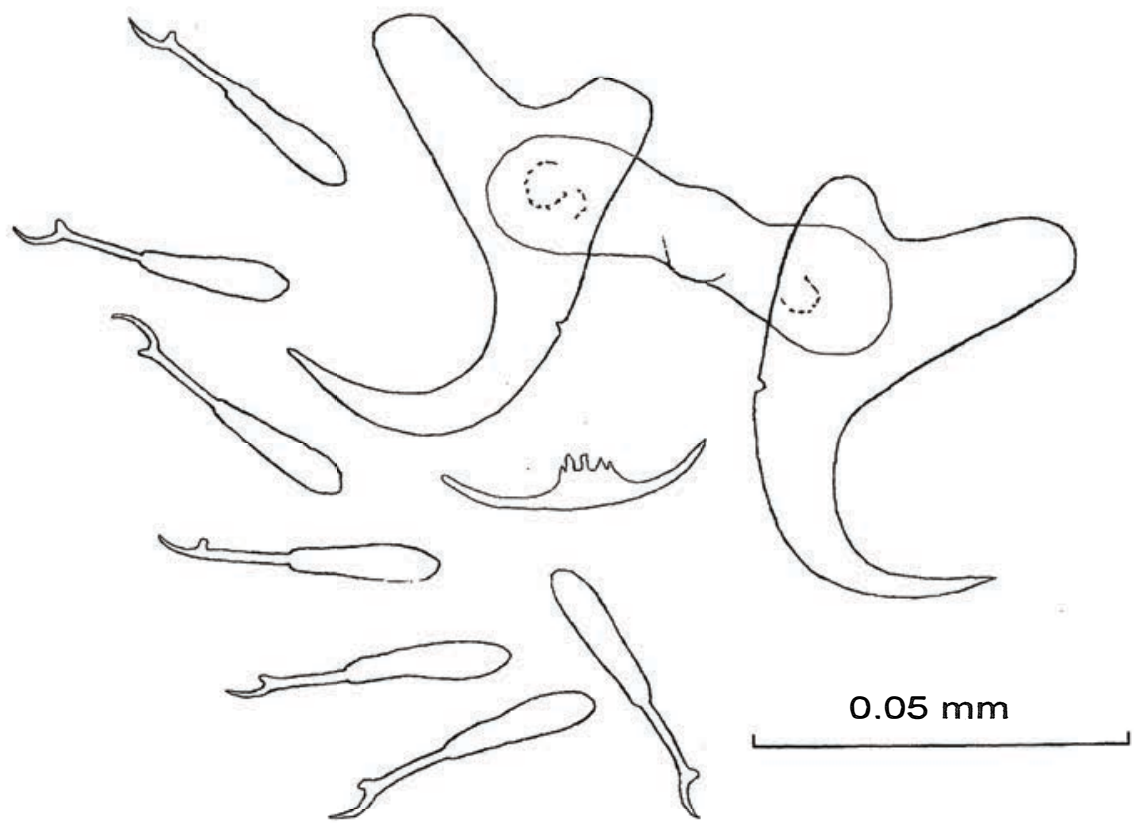

Fig. 1. Elements of attachment apparatus of Dactylogyrus triappendixis sp. $\mathbf{n}$.

Supplementary bar (ventral) substantially smaller, thin, delicate, slightly arched, widened indistinctly in its central part and difficult to observe. Medial margin with 4-6 very small processes at widened area (Fig. 1). Dimensions of bar: 3-7 × 24-37 $\mu \mathrm{m}$.

Armament of male copulatory organ of complex structure (Figs. 2-6). Support part consisting of lower, elongated, wide shaft and three upper processes. First of them robust, long, terminating with hook. Two small swellings on its hook-like bend, visible only a certain angle. Outgrowth terminating as robust, wide hook, which partly embraces copulatory tube branching from base of this process. Second process, running parallel to first one, also long, although substantially delicate, with very thin end reaching tip of copulatory tube. On some preparations, distinct branching visible on end of this process (Figs. 4, 5). Third process shorter and reaching almost to mid-length of first process. Fine denticulation occurring on its lateral margin (Fig. 2). Second and third processes not always clearly visible. Wide base of copulatory tube located in anterior part of shaft. Tube proper slightly narrower, arched and directed towards hook-like process of support part. Total length of copulatory organ of mature specimens: $105-126 \mu \mathrm{m}$, while in slightly younger individuals $-84-96 \mu \mathrm{m}$. 

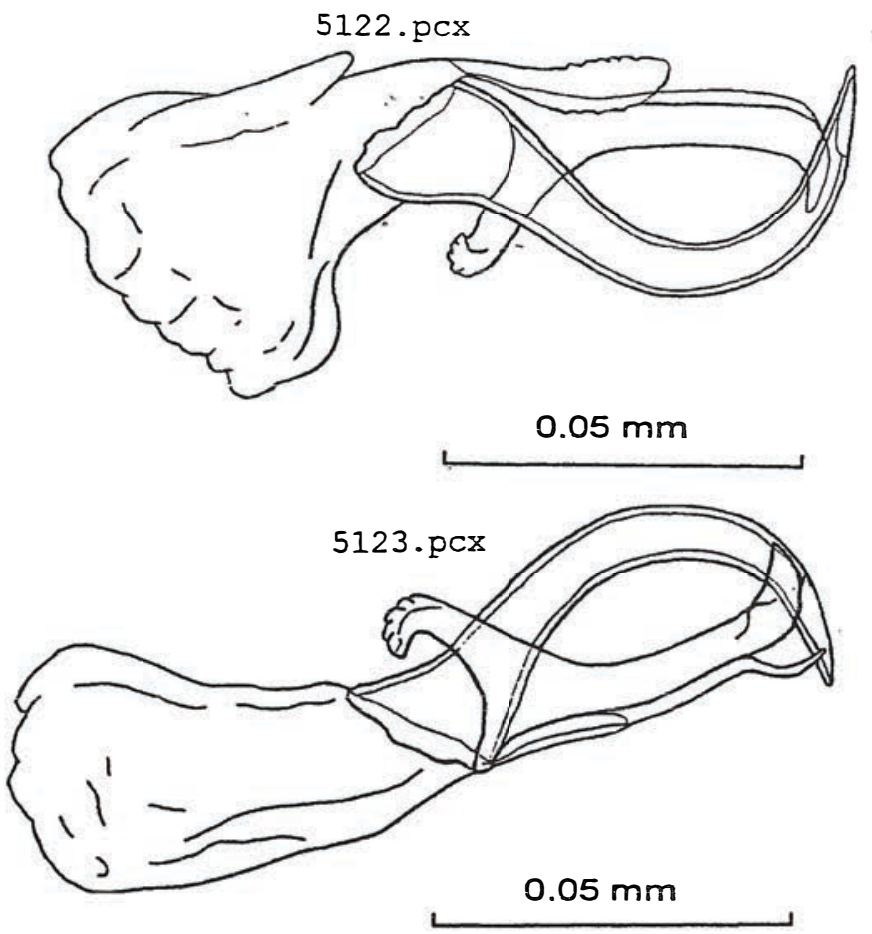

$5125 \cdot \mathrm{pcx}$
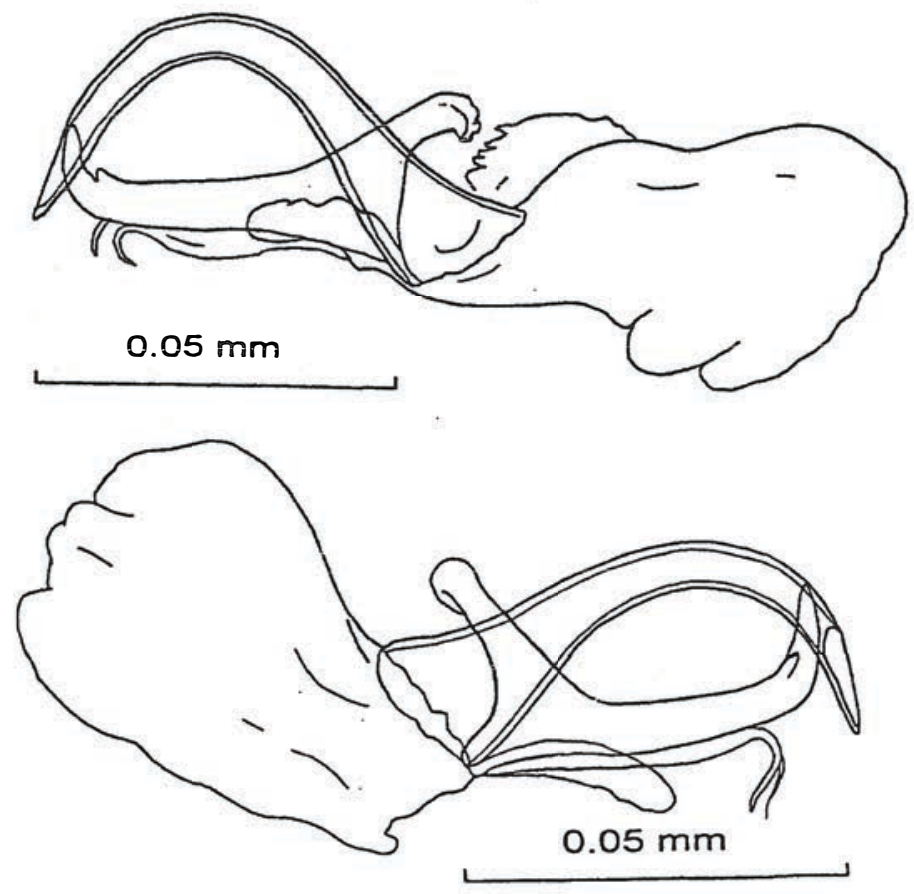

Fig. 2-5. Male copulatory organs of adults Dactylogyrus triappendixis sp. $\mathbf{n}$. 


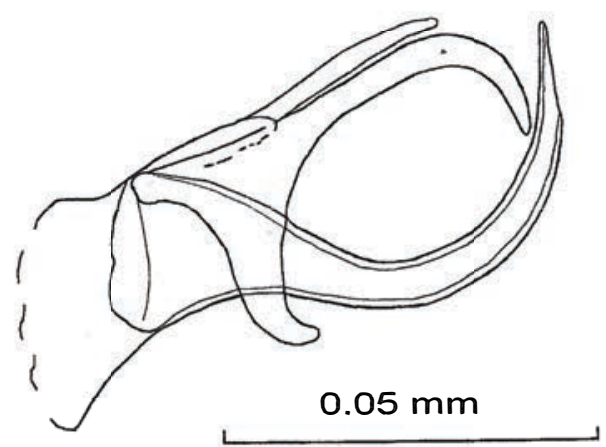

Fig. 6. Male copulatory organs of younger specimen of Dactylogyrus triappendixis $\mathbf{s p .} \mathbf{n}$.

Armament of vagina, as distinctly marked oval ring located on surface of very fine plate. This ring situated always next to, well visible, arched edge (Fig. 7). Dimensions of ring: 6-9 × 9-13 $\mu \mathrm{m}$ (ring with distance from arched edge $-9-16 \mu \mathrm{m}$.

\section{$5128 \cdot \mathrm{pcx}$}

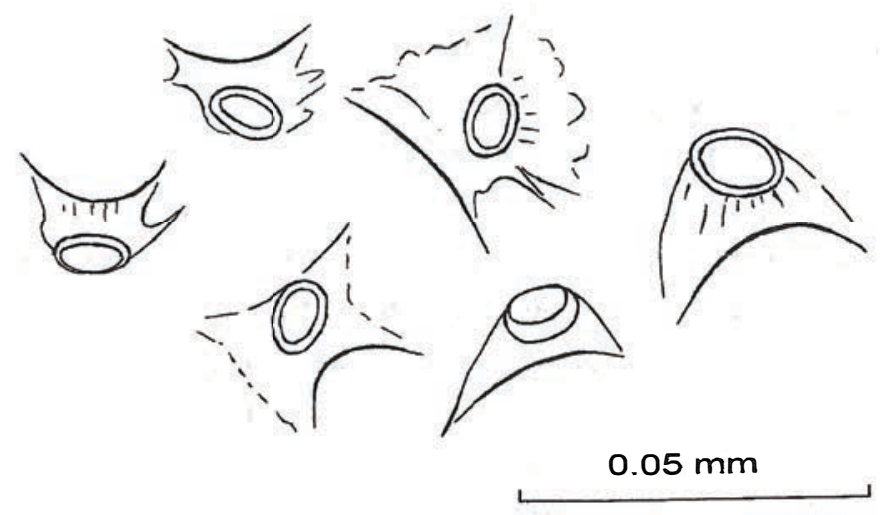

Fig. 7. Vaginal armament of Dactylogyrus triappendixis $\mathrm{sp.} \mathbf{n}$.

Eggs (Fig. 8) measuring 60-117 $\times 43-83 \mu \mathrm{m}$, filament - up to $17 \mu \mathrm{m}$.

The prevalence of this species infecting the tench was $4.76 \%$ in Ińsko Lake, $83,33 \%$ in Woświn Lake, and $100 \%$ in Mielno Lake. Single fish yielded from 6 to 50 specimens of the parasite. In May, at the water temperature in the lake about $12^{\circ} \mathrm{C}$, only single individu- 


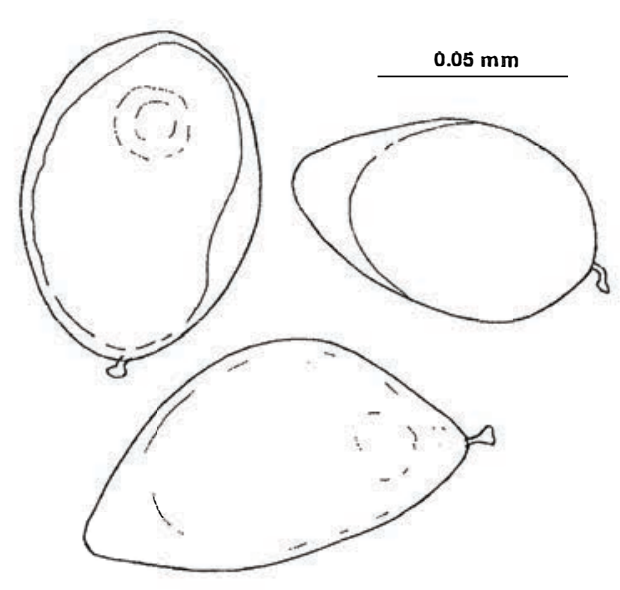

Fig. 8. Eggs of Dactylogyrus triappendixis sp. n.

als were encountered. By the end of June, however, while the water temperature reached some $18^{\circ} \mathrm{C}$, the parasites intensively reproduced. At that time, numerous adult specimens, their eggs, as well as the juveniles, were found on the gills.

\section{DISCUSSION}

Comparing the presently found parasites with the descriptions of the currently known species of the genus Dactylogyrus we have found the closet similarity with D. tincae. Gusev (1965) describing the latter species provided detailed measurements of the parasites, as well as the drawings of the opisthohaptor and male copulatory organ. Subsequently Ergens and Lom (1970) supplemented this description publishing additional illustrations of the vaginal plate.

Despite the close similarity of the morphological and morphometric characters of D. tincae and the newly described species, there are very distinct differences between them. They concern the structure of the male copulatory organ and the armament of the vagina. D. tincae has one robust process with and outgrowth in the support area of the copulatory organ (Gusev 1965, 1985; Ergens and Lom 1970). In the presently found material, the specimens were equipped with three different processes in the support part of this organ. In addition to the robust process with outgrowth, almost identical as it was in D. tincae, they had two additional processes (long and short), branching from the base of the support part of the copulatory organ (Fig. 2-6). The armament of the vagina of D. tincae consisted of the ring and the plate, the latter approximating triangle with fuzzy edges (Ergens and Lom 1970). The parasites in our own material had the ring and a delicate not very regular plate (Fig. 7), the latter always different from that of $D$. tincae.

In the presently studied material we have not encountered the second species specific for the tench $-D$. macracanthus. It differs very distinctly from $D$. triappendixis $\mathrm{sp}$. $\mathrm{n}$. and $D$. tincae with the structure of the male copulatory organ, with the smaller dimensions of this organ and with the lack of a vaginal armament. 


\section{RECAPITULATION}

1. The parasites of the genus Dactylogyrus, presently recovered from the gills of the tench, differ substantially from the hitherto described. species with the structure of their male copulatory organ and with the structure of the vaginal plate.

2. The above differences permit us to conclude that the presently found parasites represent a separate species, which was described in this paper as Dactylogyrus triappendixis sp. n.

3. It is a frequent parasite of the tench in the studied water bodies at the water temperature of about $18^{\circ} \mathrm{C}$.

\section{REFERENCES}

Baturo B., 1978: The comparison of the parasitofauna of tench fry (Tinca tinca) from pond and cage culture. Fourth International Congress of Parasitology 19-26 August 1978, Warszawa, sec. C: $200-201$.

Ergens R., J. Lom, 1970: Původci parasitárních nemocí ryb [Causative agents of parasitic fish disease]. Československé Akad. Věd, Praha: 149-197. (In Czech).

Grabda J. (ed.), 1971: Katalog fauny pasożytriczej Polski. II. Pasożyty kragłoustych i ryb [Catalogue of parasite fauna of Poland. II. Parasites of fishes and cyclostomates]. PWN, Warszawa-Wrocław: 61-68. (In Polish).

Gusev A.V., 1965: O daktilogirusach s linja Tinca tinca (L.) [About species of the genus Dactylogyrus from tench Tinca tinca (L.).] Tr. Zool. In-ta AN SSSR, 35: 126-131. (In Russian).

Gusev A.V., 1985: Parazitičeskije mnogokletočnyje. V: Opredelitel' parazitov presnovodnych ryb fauny SSSR (Ed. Bauer O.N.). 2 [Parazitic metazoans. In: Key of the parasites of the freshwater fishes of the USSR]. Izd. Nauka, Leningrad: 64-65. (In Russian).

Markevič A.P., 1951: Parazitofauna presnovodnych ryb Ukrainskoj SSR [Parasitic fauna of freshwater fishes of the Ukrainian SSR.JIzd. AN USSR, Kiev: 200-201. (In Russian).

Pucilowska A., 1973: Monogenea ryb dorosłych z Zalewu Zegrzyńskiego [Monogenea of mature fishes of Zegrzyński Reservoir.] Materiały XI Zjazdu Polskiego Towarzystwa Parazytologicznego, 10-12 May 1973, Poznań: 146. (In Polish). 


\section{Jadwiga WIERZBICKA, Dominik GRONET \\ DACTYLOGYRUS TRIAPPENDIXIS SP. N. (MONOGENEA) \\ PASOŻYT LINA, TINCA TINCA (L.) \\ STRESZCZENIE}

Podano szczegółowy opis nowego gatunku Monogenea Dactylogyrus triappendixis pasożytującego na skrzelach lina, Tinca tinca (L.) z jezior północno-zachodniej Polski. Gatunek ten różni się elementami budowy męskiego narządu kopulacyjnego i uzbrojeniem pochwy od innych pasożytów rodzaju Dactylogyrus występujacych u lina. $D$ triappendixis $\mathrm{sp}$. n. jest częstym pasożytem lina w badanych zbiomikach przy temperaturze wody około $18^{\circ} \mathrm{C}$.

Received: 27 January 1997

Author's address:

Jadwiga Wierzbicka PhD DSc

Dominik Gronet MSc

Department of Fish Diseases

Agricultural University of Szczecin

Kazimierza Królewicza 4, 71-550 Szczecin, Poland 